EDITORIAL

NEUROUROLOGY \& URODYNAMICS

\title{
TOTAL TAPE BAN: NOT THE ANSWER! $!^{1}$
}

Bernard T. Haylen 0000-0001-5436-2435 0000-0001-5436-

2435, Joseph K.S. Lee

Vasukhi Sivagnanam and Christopher F. Maher

\author{
University of New South Wales, Sydney. N.S.W. Australia \\ Bernard T. Haylen MB BS MD FRANZCOG FRCOG CU Urogynaecologist \\ Joseph KS Lee MB ChB FRANZCOG CU Urogynaecologist
}

St Vincent's Hospital, Sydney. N.S.W. Australia

Vasukhi Sivagnanam MB BS Dip Obs MRANZCOG Fellow in Urogynaecology

University of Queensland, Brisbane. Queensland. Australia.

Christopher F. Maher MB BS PhD FRANZCOG CU Urogynaecologist

\footnotetext{
${ }^{1}$ This is the author manuscript accepted for publication and has undergone full peer review but has not been through the copyediting, typesetting, pagination and proofreading process, which may lead to differences between this version and the Version of Record. Please cite this article as doi:10.1002/nau.23794
} 
Correspondence to:

Professor B.T. Haylen,

Suite 904, St Vincent's Clinic,

438 Victoria Street,

Darlinghurst. 2010.

N.S.W. AUSTRALIA.

Ph: \#\# 61- 2- 83826983

Fax: \#\# 61 - 2 - 83826984

bernard@haylen.co

Conflicts of interest: Authors 1,3,4 (Nil COI); Author 2 (COI disclosed)

NEUROUROLOGY \& URODYNAMICS

\title{
TOTAL TAPE BAN: NOT THE ANSWER!
}

\author{
Bernard T. Haylen, Joseph K.S. Lee \\ Vasukhi Sivagnanam and Christopher F. Maher
}

University of New South Wales, Sydney. N.S.W. Australia

Bernard T. Haylen MB BS MD FRANZCOG FRCOG CU Urogynaecologist Joseph KS Lee MB ChB FRANZCOG CU Urogynaecologist 
St Vincent's Hospital, Sydney. N.S.W. Australia

Vasukhi Sivagnanam MB BS Dip Obs MRANZCOG Fellow in Urogynaecology

University of Queensland, Brisbane. Queensland. Australia.

Christopher F. Maher MB BS PhD FRANZCOG CU Urogynaecologist

Correspondence to:

Professor B.T. Haylen,

Suite 904, St Vincent's Clinic,

438 Victoria Street,

Darlinghurst. 2010.

N.S.W. AUSTRALIA.

Ph: \#\# 61- 2- 83826983

Fax: \#\# 61 - 2 - 83826984

bernard@haylen.co

Conflicts of interest: Authors 1,3,4 (Nil COI); Author 2 (COI disclosed)

\section{TOTAL TAPE BAN: NOT THE ANSWER!}

On $10^{\text {th }}$ July, 2018, it was announced that all mid-urethral slings (MUS - known commonly and defined $^{1}$ as "tapes") for stress urinary incontinence (SUI) would be suspended ("paused") in England for at least nine months ${ }^{2}$. This appears to follow sustained public criticism by patients in regard to complications. An extension of this measure to Northern Ireland appears likely. It comes after the suspension of continence tapes for use in Scotland in $2014^{3}$, a ruling (reportedly) reversed in March 
$2017^{4}$. The English ban brings to reality the scenario addressed in an article published below in this journal's current issue "What if there were no tapes" ${ }^{5}$. At the time of preparation, the article was semi-speculative in response to regulatory changes and restrictions on all mesh and certain tapes (those without sufficient scientific evidence) in Australasia ${ }^{6,7}$.

The article examines the significant benefits of tapes over a full range of alternate surgeries for SUI. It concludes ${ }^{5}$ : "In the haste for some countries to severely restrict or abandon the use of tapes for SUI, authorities should be cognizant that they are leaving their incontinence sufferers and the clinicians who treat them with overall inferior surgical treatment options. The experience of many clinicians with any of these alternate options might be little or none. The inherent danger to patients with surgeons returning to these options may be far greater than leaving in use, tapes of proven efficacy and safety". The proviso would be that the surgeons would be appropriately qualified and have sufficient ongoing experience in SUI surgery using tapes. It is to be noted that, on 2013-2014 figures, 24 tapes are inserted in England for each alternate continence procedure ${ }^{8}$. Re-learning traditional procedures would be a challenge for most surgeons with variable "learning curve" morbidity.

We recognise that it is undesirable that women should be left with ongoing and difficult-to-treat pain issues, if this was a significant consideration in the English decision. An extensive Cochrane review $^{9}$ of transobturator (side-to-side through the obturator space) tapes showed $2-21 \%{ }^{9}$ of women developed significant post-surgical groin or limb pain. Seklehner et $\mathrm{al}^{10}$ reported neurological symptoms (groin or thigh pain or associated neurological symptoms) were nearly three times more common after the transobturator tapes than the retropubic tapes and occurred in $9.5 \%$ of those having obturator MUS's. As the management of groin pain after transobturator tapes is challenging, the surgery to totally remove the tapes is difficult and the outcomes unpredictable ${ }^{11-13}$, women need to be fully informed prior to considering the transobturator tapes. 
A total ban on all tapes will, however, leave incontinence sufferers $(13-45 \%$ of an adult female population $^{14}$ or $40 \%$ persistent after childbirth ${ }^{15}$ with up to $20 \%$ requiring surgery ${ }^{16}$ ) and their surgeons with no "first-line" minimally invasive surgical option.

What then, are the regulators' respective stances internationally (outside of England) with regards to pelvic floor prostheses? The position in Australia and New Zealand since early 2018 has been similar: a clear distinction has been made between tapes for SUI and "mesh" for pelvic organ prolapse (POP). Transvaginal mesh will be unavailable whilst the range of "tapes" will be limited to those with sufficient scientific evidence of safety and efficacy ${ }^{6,7}$. The Australian Commission on Quality and Safety in Health Care have completed their review of tapes for SU ${ }^{17}$ and have preferenced towards retropubic mid-urethral slings for SUI over the transobturator tapes based on the data presented above. This seems an appropriately measured response and allows an avenue for change in the pathway as evidence and data matures. The so called "mini-slings" are excluded due to the lack of quality data. New surgical accreditation guidelines have been introduced dependent on surgical volume and training amongst other criteria.

With regards to North American regulators, the U.S. Food and Drug Administration (FDA) ${ }^{18}$ in July 2011 re-classified transvaginal mesh used specifically for POP as "high risk" whilst maintaining tapes used for SUI as "low risk". They state on their website that "The safety and effectiveness of multiincision slings (tapes) is well-established in clinical trials that followed patients for up to one-year." The Society of Urodynamics, Female Pelvic Medicine and Urogenital Reconstruction (SUFU) ${ }^{19}$, American Urogynecologic Society $(A \cup G S)^{19}$, supported by other professional bodies, and the American Urological Association $(A \cup A)^{20}$ released position statements strongly supporting the FDA decision in regard to tapes for SUI.

In a recent development (June 2018), the FDA ${ }^{21}$ re-classified the manual surgical instruments used in most pelvic floor surgical prostheses from Class I to Class II, requiring much greater evidence of their 
safety and efficacy for substantial equivalence in premarket notification. Distribution of those tapes involved $^{22}$ has stopped, temporarily withdrawing them from the market.

In 2010, Health Canada ${ }^{23}$ issued a Notice to Hospitals (NtH) alerting surgeons about complications associated with transvaginal mesh use for SUI and POP and continue to monitor complications of these procedures. Thus, neither mesh nor tapes are currently banned in North America.

In 2015, the European Commission ${ }^{24}$ enquiry on the safety of surgical meshes supported the use of tapes for women seeking surgery for SUI. They qualify this by stating that health professionals must be appropriately trained in the procedure.

We maintain the view expressed in our article ${ }^{5}$ regarding the safety and efficacy of retropubic tapes in experienced surgical hands and their superiority over other continence procedures and we are fully supportive of audited practice. Banning all continence tapes we believe is regressive and "not the answer": it limits the choices for women seeking surgical relief for SUI whilst exposing them to possible additional morbidity and poorer outcomes associated with alternative options.

\section{References}

1. Haylen BT, Freeman RM, Swift SE, Cosson M, Davila GW, Deprest J, Dwyer PL, Fatton B, Kocjancic E, Lee J, Maher C, Rizk DE, Petri E, Sand PK, Schaer GN, Webb R. An International Urogynecological Association (IUGA) / International Continence Society (ICS) Joint Terminology and Classification of complications related directly to the insertion of prostheses (meshes, implants, tapes) and grafts in female pelvic floor surgery. Int Urogyn J 2011; 22: 3-15; Neurourol Urodyn 2011; 30(1): 2-12. Dual Publication.

2. Update on the Independent Medicines and Medical Devices Safety Review: Written statement - HCWS841. Published July 2018. Available at: https://www.parliament.uk/business/publications/written-questions-answersstatements/written-statement/Commons/2018-07-10/HCWS841/

3. Morling JR, McAllister DA, Agur W, et al. Adverse events after first, single, mesh and nonmesh surgical procedures for stress urinary incontinence and pelvic organ prolapse in Scotland, 1997-2016: a population-based cohort study. Lancet 2017; 389(10069): 629-40. 
4. The Scottish Independent review of the use, safety and efficacy of transvaginal mesh implants in the treatment of stress urinary incontinence and pelvic organ prolapse in women: Final Report. http://gov.scot/publications/2017/03/3336.

5. Haylen BT, Lee J, Sivagnanam V, Cross A. What if there were no tapes? Neurourol Urodyn 2018; https://doi.org:10.1002/nau.23741

6. http://www.medsafe.govt.nz/hot/alerts/UrogynaecologicaSurgicalMeshImplants.asp

7. https://www.tga.gov.au/alert/tga-actions-after-review-urogynaecological-surgical-mesh/Jan 17,2018 [accessed Jan 2018]

8. Health and Social Care Information Centre. Hospital episode statistics. Available at: www.hscic.gov.uk/hes [Accessed July 18, 2018].

9. Ford AA, Rogerson L, Cody JD, Aluko P, Ogah JA. Mid-urethral sling operations for stress urinary incontinence in women. Cochrane Database of Systematic Reviews 2017, Issue 7. Art. No.: CD006375. DOI: 10.1002/14651858.CD006375.pub4

10. Seklehner S, Laudano MA, Xie D, Chughtai B, Lee RK. A meta-analysis of the performance of retropubic mid urethral slings versus transobturator mid urethral slings. J Urol 2015; 193(3): 909-15.

11. Duckett J, Baranowski A. Pain after suburethral sling insertion for urinary stress incontinence. Int Urogyn J 2013; 24(2): 195-201.

12. Cundiff GW, Quinlan DJ, van Rensburg JA, Slack M. Foundation for an evidence-informed algorithm for treating pelvic floor mesh complications: a review. BJOG 2018; 125(8): 102637.

13. Reynolds WS, Kit LC, Kaufman MR, Karram M, Bales GT, Dmochowski 0000-0002-9838-9178 0000-0002-9838-9178 RR. Obturator Foramen Dissection for Excision of Symptomatic Transobturator Mesh. J Uro 2012; 187(5): 1680-4.

14. Botlero R, Urquhart DM, Davis SR, Bell RJ. Prevalence and incidence of urinary incontinence in women: Review of the literature and investigation of methodological issues. Int J of Uro 2008.15(3): 230-233. 
15. MacArthur C, Wilson D, Herbison P, Lancashire RJ, Hagen S, Toozs-Hobson P, et al. Urinary incontinence persisting after childbirth: extent, delivery history, and effects in a 12-year longitudinal cohort study. BJOG 2015; https://doi.org/10.1111/1471-0528.13395

16. Maher $C$. Vaginal mesh controversy shows collective failure of the TGA and Australia's specialists. The Conversation. Published June 2017. Available at:

http://theconversation.com/vaginal-mesh-controversy-shows-collective-failure-of-the-tgaand-australias-specialists-78605

17. ACQSHC. Care pathway for the management of Stress Urinary Incontinence 2018.

https://www.safetyandquality.gov.au/wp-content/uploads/2018/02/TV-mesh-Surgical-CarePathway-SUI-portrait.pdf [Accessed July 14, 2018].

18. Food and Drug Administration and Centre for Devices and Radiological Health. Urogynecological surgical mesh: Update on the safety and effectiveness of transvaginal placement for pelvic organ prolapse. Published July 2011. [Accessed July 15, 2018]. Available at:

https://www.fda.gov/downloads/MedicalDevices/Safety/AlertsandNotices/UCM262760.pdf

19. American Urogynecologic Society and Society of Urodynamics, Female Pelvic Medicine and Urogenital Reconstruction. Position statement on mesh midurethral slings for stress urinary incontinence. [Accessed July 15, 2018]. Available at:

http://sufuorg.com/docs/guidelines/augs-sufu-mus-position-statement-approved-1-32014.aspx

20. American Urological Association. AUA position statement on the use of vaginal mesh for the surgical treatment of stress urinary incontinence. [Accessed July 15, 2018]. Available at: https://www.auanet.org/education/vaginal-mesh-for-sui.cfm

21. https://www.federalregister.gov/documents/2017/01/06/2016-31862/obstetrical-andgynecological-devices-reclassification-of-surgical-instrumentation-for-use-with

22. https://www.augs.org/gynecare.tvt-abbrevo-and-tvt-obturator/

23. Health Canada. Surgical mesh - Complications associated with transvaginal implantation for the treatment of stress urinary incontinence and pelvic organ prolapse - Notice to hospitals. [Accessed July 15, 2018]. Available at: http://www.healthycanadians.gc.ca/recall-alertrappel-avis/hc-sc/2014/39475a-eng.php 
24. European Commission Scientific Committee on Emerging and Newly Identified Health Risks. Opinion on: The safety of surgical meshes used in urogynecological surgery. [Accessed July 15, 2018]. Available at:

https://ec.europa.eu/health/sites/health/files/scientific_committees/emerging/docs/scenih r_o_049.pdf 


\section{University Library}

\section{- M M I E E R VA A gateway to Melbourne's research publications}

Minerva Access is the Institutional Repository of The University of Melbourne

Author/s:

Haylen, BT;Lee, JKS;Sivagnanam, V;Maher, CF

Title:

Total tape ban: Not the answer!

Date:

2018-08

Citation:

Haylen, B. T., Lee, J. K. S., Sivagnanam, V. \& Maher, C. F. (2018). Total tape ban: Not the answer!. Neurourol Urodyn, 37 (6), pp.2035-2037. https://doi.org/10.1002/nau.23794.

Persistent Link:

http://hdl.handle.net/11343/284816 